\title{
Should we care about what the students do? Challenging how we design for online learning
}

\author{
Bettina Schwenger \\ Swinburne University of Technology
}

\begin{abstract}
Rapidly responding in the times of a pandemic, tertiary courses in New Zealand have implemented emergency remote learning and teaching by increasing learning online. Many staff require support though to purposeful redesign and facilitate online as part of blended or hybrid learning and teaching. This article reports about a study of redesign for such a purpose. The course demands were identified to then consider how to use online features to support the assessment for Māori and non-Māori students. Research instruments with students included questionnaires and focus groups; conversations and reflections were used with staff. The paper includes key findings, firstly how online features can contribute to active learning and secondly, considerations and tools to enhance a course design with increased online learning, for example an explicit plan of how and when certain affordances support students learning.
\end{abstract}

Keywords: design for online learning, hybrid learning, blended learning, first-year undergraduate

\section{Introduction}

The sudden replacement of face-to-face through online facilitation during the first semester in 2020 has resulted in institutions and teachers questioning existing course design models and looking to blended or hybrid learning for adding new opportunities, for example by integrating appropriate online technologies with campus-based learning and teaching. Blended or hybrid learning has been defined as identifying the best mix of online and face-to-face learning and teaching by combining or integrating the right features for what students are to learn and do in a course (Caulfield, 2011). This paper reports of one part in a study that took place in a first-year undergraduate course in the Bachelor of Teaching (ECE) at a New Zealand tertiary institution. The study responds to questions and concerns that are even more pertinent in the current environment. Reacting to policy changes for more online learning outside the classroom, the two teachers wanted to use the course page in the institutional learning management system to increase flexibility in when and how students learn. However, the students did not seem to use the course page frequently. Additionally, the teachers were concerned about improving the students' digital literacies, for example their applied digital information literacy (DIL) in the ePortfolio assessment. Therefore, the research investigated how online features could be used in an in(ter)vention to achieve these goals. As suggested by my Māori colleagues who supported the study, I use the term in(ter)vention, firstly to diminish negative connotations of deficit associated with the word intervention, a concept which as such does not exist in the Māori world, and secondly, to recognise that the four resources were part of an innovative response to real-world issues.

\section{Common challenges of designing for online learning}

In a systematic literature review of 640 sources, Boelens, De Wever and Voet (2017) identified that courses with both online and face-to-face learning often lack flexibility and interaction online. Challenges reported by Ako Aotearoa and Synapsys (2018) include achieving program and course design that uses the appropriate technology and offers effective learning to achieve a particular outcome. To harness the potential of online learning and its features or affordances requires planned development (Conole, 2013; Moskal, Dzuiban \& Hartman, 2013) to avoid static course pages.

To move from an online repository, where resources are merely for students to read, requires a design that is based on what students do to learn and engages them (Biggs \& Tang, 2011; Laurillard, 2012; Mayes \& de Freitas, 2013). To reflect learning outcomes, blended learning should contain elements for learning as behavior, as the construction of knowledge and meaning, and as social practice (Mayas \& de Freitas, 2013). Even digital- savvy teachers can be unsure how to achieve, for example, interaction online that reflects the course outcomes and the type of learning required to support students study success appropriately. The research was set up to find out how to design for online as part of blended learning, to increase interaction outside the classroom in an undergraduate course, and support Māori and non-Māori students with the ePortfolio assessment. 


\section{Research approach}

Educational Design Research (EDR) offers a phased, structured and reflective approach, is theory informed and aims at designing real-life interventions (Plomp, 2013). The research was conducted through a three phase model, informed by Plomp (2013) and included preliminary research, development and evaluation phase (Figure 1). Kaupapa Māori as part of the methodological approach has ensured the maintenance of cultural integrity (Pihama, 2010) in research with Māori and non-Māori in an appropriate and culturally safe way. Guided by Cram's (2001) Kaupapa Māori researcher guidelines and L. T. Smith (2012) cultural values, these can help to work respectfully and appropriately with indigenous people. Examples of these values include treating participants with respect for their dignity, listening and meeting people face-to-face as well as being cautious and reflective (Cram, 2001). Thirteen students and two teachers participated in the study during 2016. Students shared their thoughts through initial and final questionnaires and initial foci groups; teachers through initial questionnaire and interviews, reflective prompts, emails and a final interview.

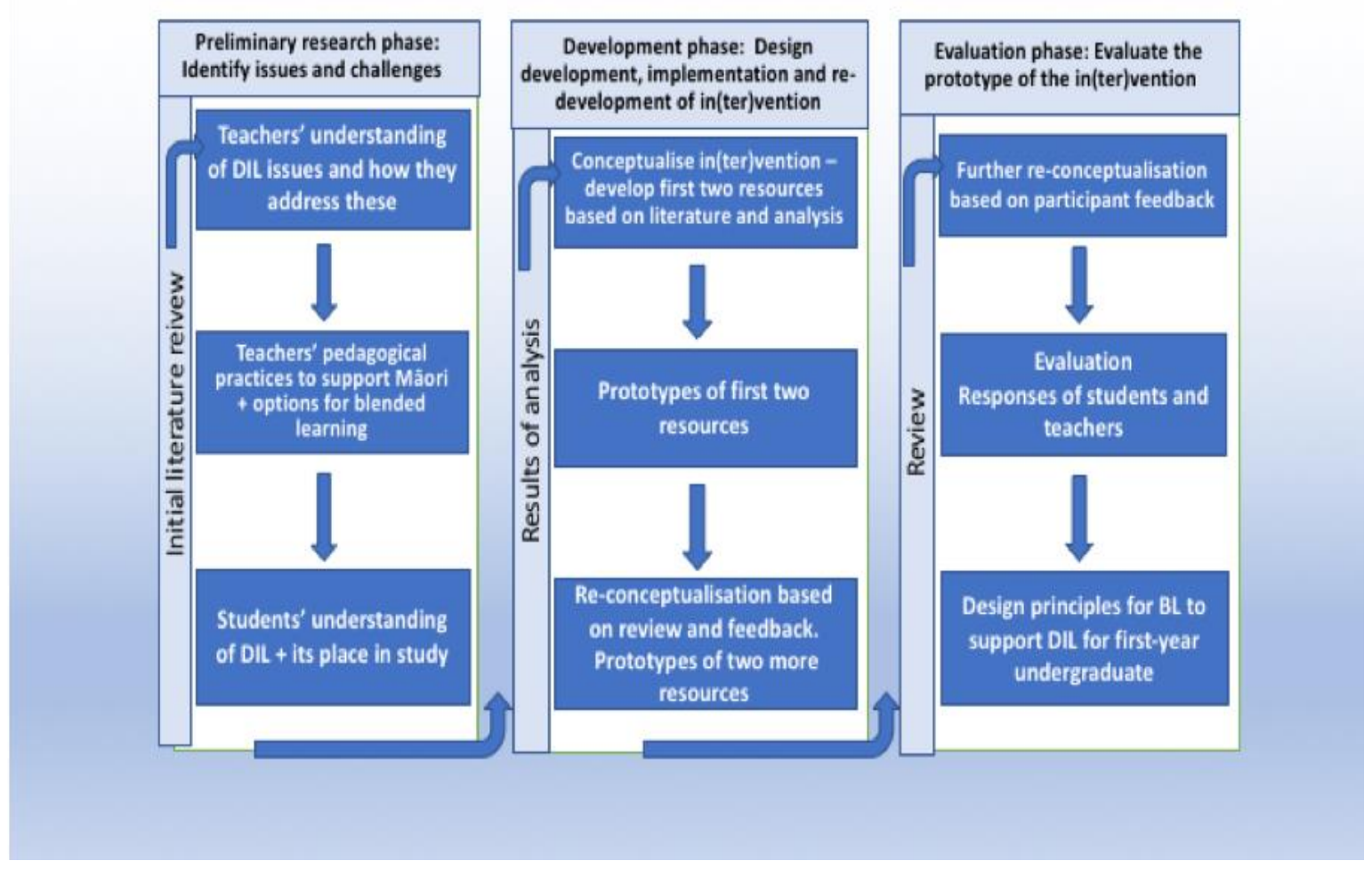

Figure 1: Overview of the three research phases.

Various steps were taken to investigate the research question How can teachers design blended learning for firstyear undergraduate students to acquire digital information literacy. These included a literature review of related research and of projects to date, identifying the existing design, challenges and resources, consulting, drafting, responding to feedback based on communication, relationships and ongoing collaboration. Feedback from Māori staff and colleagues helped to fine-tune the in(ter)vention. The resources offered students opportunities to apply, practice and reflect upon using digital information literacy (DIL) in situations where they are required to create new information, as advised by Hugh, Bruce and Edwards (2007). The four resources were situated in the course demands and were available for the students on the course page:

- Process: How do I use information to develop an ePortfolio? Students familiarise themselves with the visualised six step process (Figure 2) and reflect through questions what each step means for their course work and the ePortfolio.

- Scenario: Students apply the six-step process and receive automated feedback on decisions made. They proceed with DIL practices in an ECE situation to create an entry in their ePortfolio.

- Quiz: A quiz with formative feedback to practice DIL for the ePortfolio.

- One-page process with reflective pop-up questions. 


\section{Findings}

The design intentions for all resources were to provide flexible interaction through practice, reflection and feedback opportunities using online features. The growing flexibility and independence of studying online can be difficult for students to manage so it was of interest how these affordances can scaffold learning. By using screenshots, step-by-step instructions and structured reflective elements to support self-assessment, the study aimed to offer comprehensive support if needed in this first-year course. Both teachers reconfirmed during the study that they appreciated the online affordances of the resources on an otherwise mostly static course site but they were unsure if one affordance had been more useful than others to increase flexibility and active learning for students. Both teachers appreciated an inquiry-learning approach and reported to engage students in constructivist and situated activities in the classroom but were unsure how to transfer the approach online.

The resource design was based on pedagogically sound principles of applied learning theories by recognizing the type of learning required to support students' assessment and offering authentic resources situated in the course demands. It addressed the identified need according to both teachers; little data exists to understand how a particular affordance such as the automated feedback was useful for Māori and non-Māori students. Compared to the resources with practice opportunities, online interactivity and formative feedback, the fourth, one-page printable resource which was a summary of the underpinning process, was evaluated as most useful by Teacher A at the end of the study. This was surprising for several reasons. Firstly, the teachers reconfirmed how they appreciated the online affordances of the resources throughout the study. Secondly, Teacher A and Teacher B supported the intention behind the resources of the in(ter)vention as to enable personalised, flexible learning and differentiated facilitation as recommended by Boelens et al. (2017), and Teacher A was very interested to create resources for such a purpose in the near future. It raises the question of how the teachers perceived the value of online affordances, although the teachers' responses may have been based on students' requests.

\section{Contribution and limitations of the study}

Although this article does not report the evaluation of the study, in the following some of the formative and summative feedback received are outlined. Teachers appreciated the explicitness of the resources and felt that connecting development with the assessment supported students' assessment success. The teachers reported anecdotal feedback from six students in the first semester who found the tools helpful. Feedback given on four ePortfolio assessments to students at the end of semester 1 showed a positive development in the use of literature in the ePortfolios. Feedback from seven students in a questionnaire at the end of the year indicated that the resources had been useful for their independent study, to develop the necessary actions of the process and successfully prepare the ePortfolio. The teachers confirmed several times explicitly how they valued the integrated online resources to foster students DIL capabilities. At the start of Semester 2, Teacher A reported that the literature in the assignments of the February intake in Semester 1 was of better quality. DIL was more explicitly discussed in the classroom in the first semester, including the introduction of the online resources, and it might have made students more aware of the importance to find quality information.

I recognise that the findings from students, in particular, are limited which is partially due to the small number of Māori and non-Māori participants in each semester. The findings are from a particular situation, a first- semester course in the Bachelor of Teaching (ECE) with two cohorts. These findings can, however, inform academic developers, course designers and teachers who consider the potential of online features to support flexible learning and design principles for online learning that supports students' study success. It was an authentic experience, in a time of ongoing institutional change. The study contributed to our understanding of the complexity of change initiatives and collaboration and it touched on bigger issues related to learning design that can be expected to surface similarly in other contexts.

\section{Discussion and conclusion}

The content of the four online resources was situated in early childhood education and aligned with the learning to be achieved, focused on practices that students required for ePortfolio assessment, and targeted areas that teachers and students had identified as troublesome. This close alignment helped to ensure the relevance of the resource content, to determine the type of learning required and identify which characteristics could be used to enhance students' learning. Through the literature review I had identified some positive affordances of the 
technologies and some associated constraints to inform the design decisions as recommended by Conole (2013).

The resources used online features to offer active learning away from the classroom for developing DIL. They were designed to provide initial advice with reflective questions to consider, to apply in a situation and correct through automated feedback. The Moodle resources Quiz and Lesson offered unlimited practice opportunities and automated feedback for students to experience timely formative "feedback during learning" as "the most powerful enhancement to learning" (Biggs \& Tang, 2011, p. 97). Through online affordances, such feedback was achieved without adding to teachers marking time which can be a strong barrier to providing formative feedback (Feekery, 2013). The resources utilised automated feedback and unlimited practice opportunities to enable effective learning and teaching strategies online as recommended for Māori learners in the classroom by Curtis et al. (2011) and Sciascia and Aguayo (2016). All learning resources supported flexible learning with reflective questions and prompts. These technical affordances can be used to scaffold self-assessment, and active learning, and to encourage students to practise and learn independently. Therefore, they afford strategies that have been identified to support the learning of Māori (Curtis et al., 2011; NZCER, 2004; Sciascia \& Aguayo, 2016) and of non-Māori students (Conole, 2013, 2016; Hattie, 2008). Some of the students confirmed in their feedback that the online resources have assisted with preparing for assessment tasks. This seems to indicate that the resources offered some scaffolding to students to develop independence as suggested by Churchill, King, Webster and Fox (2013) and Curtis et al. (2011). Students' responses seem to indicate further that automated feedback can support independent learning skills.

The study results cannot answer the question of how online feedback and other features can be fully utilised as technical affordances to develop interaction online and support independent learning. The research has confirmed, though, that online features can provide new learning opportunities to support assessment, digital information literacy (DIL) development and flexible learning in a first-year undergraduate course. The features of the online resources seem to have enabled the development of practices and processes relevant for the assessment in this course and others in the qualification. The online affordances of the course site seemed to be underused however, and there was potential to better design for blended learning. Before the in(ter)vention, there was a gap between the collaborative, active learning approach in the classroom and a mostly static course page that students did not seem to see as relevant for their learning. It raises the question of how the teachers perceived the function of the course page in offering flexible learning. An explicit roadmap of what students are doing to learn, as one possible tool, can help to integrate online with face-to-face activities after identifying the best suitable features for the learning required.

This research confirms that we should care about what students do to learn and that more research is required in New Zealand's tertiary institutions to increase activity-based, flexible designs for online learning, reflecting what has been identified to engage Māori and non-Māori students. These should include the design and facilitation of interaction online as recommended by Ako and Synapsys (2018) and Boelens et al. (2017), scaffolding of independent learning and integration of formative feedback (Curtis et al., 2011; Sciascai \& Aguayo, 2016). The study identified examples how online affordances of LMS tools can enable these practices.

Teachers and other learning designers require support to better utilize online features for students to achieve learning outcomes. Cleary, staff capability impacts on how online affordances might be designed into and applied in courses. The teachers in this research appreciated the ongoing nature of combined capability building and course development over two semesters. Continuous institutional technical and pedagogical support is required but should be complemented by multiple ways of engaging teachers as Dyke, Conole, Ravenscroft and de Freitas (2007) emphasise - that allow teaching staff to experiment and experience, through social interactions, conversations and by thinking and reflections.

\section{References}

Ako Aotearoa \& Synapsys (2018). Technology in learning: Benchmarking and developing sector capability. Wellington, New Zealand: Ako Aotearoa

Biggs, J., \& Tang, C. (2011). Teaching for quality learning at university: What the student does (4th ed.). Maidenhead, England: McGraw-Hill, Society for Research into Higher Education, \& Open University Press.

Boelens, R., De Wever, B., \& Voet, M. (2017). Four key challenges to the design of blended learning: A systematic literature review. Educational Research Review, 22, 1-18. doi:10.1016/j.edurev.2017.06.001

Bower, M. (2008). Affordance analysis - matching learning tasks with learning technologies. Educational Media International, 45(1), 3-15. doi:10.1080/09523980701847115

Caulfield, J (2011). How to Design and Teach a Hybrid Course: Achieving Student-centered Learning through Blended Classroom, Online, and Experiential Activities. Sterling, Va.: Stylus Pub.

Churchill, D., King, M., Webster, B., \& Fox, B. (2013). Integrating learning design, interactivity, and technology. In H. Carter, M. Gosper, \& J. Hedberg (Eds.), Electric dreams. Proceedings Ascilite 2013 Sydney. (pp.139143). 
Conole, G. (2016). Theoretical underpinnings of learning design. In J. Dalziel (Ed.), Learning design: Conceptualizing a framework for teaching and learning online (pp. 42-62). New York, NY: Routledge.

Conole, G., \& Dyke, M. (2004). Understanding and using technological affordances: A response to Boyle and Cook. Alt-J, 12, 301-308. doi:10.1080/0968776042000259609

Cram, F. (2001). Rangahau Māori: Tona tika, tona pono: The validity and integrity of Māori research. In M. Tolich (Ed.), Research ethics in Aotearoa New Zealand: Concepts, practice, critique (pp. 35-52). Auckland, New Zealand: Longman.

Curtis, E., Townsend, S., Rakena, T., Brown, D., Sauni, P., Smith, A., ... Johnson, O. (2011). Teaching for student success: Promising practices in university teaching. Pacific-Asian Education Journal, 23(1), 71-89.

Dyke, M., Conole, G., Ravenscroft, A., \& de Freitas, S. (2007). Learning theory and its application to e- learning. In G. Conole \& M. Oliver (Eds.), Contemporary perspectives in e-learning research: Themes, methods and impact on practice (pp. 82-97). New York, NY: Routledge.

Feekery, A. (2013). Conversation and change: Integrating information literacy to support learning in the New Zealand tertiary context (Doctoral dissertation, Massey University, New Zealand). Retrieved from https://akoaotearoa.ac.nz/download/ng/file/group-9705/conversation-and-change-integrating-informationliteracy-to-support-learning-in-the-new-zealand-tertiary-context.pdf

Garrison, D. R., \& Kanuka, H. (2004). Blended learning: Uncovering its transformative potential in higher education. Internet and Higher Education, 7(2), 95-105. doi:10.1016/j.iheduc.2004.02.001

Gosling, C., \& Nix, I. (2011). Supported open learning: Developing an integrated information literacy strategy online. In T. Mackey \& T. Jacobson (Eds.), Teaching information literacy online (pp. 91-108). New York, NY: Neal-Schuman.

Hattie, J. (2008). Visible learning: A synthesis of over 800 meta-analysis relating to achievement. London, England: Routledge.

Hughes, H., Bruce, C. \& Edwards, S. (2007). Models for reflecting and learning: A culturally inclusive response to the information literacy imbalance. In S. Andretta (Ed.), Change and challenge: Information literacy for the 21st century (pp. 59-84). Adelaide, Australia: Auslib Press.

Laurillard, D. (2012). Teaching as a Design Science. Building pedagogical patterns for learning and technology. New York \& London: Routledge.

Mayes, T., \& de Freitas, S. (2013). Technology-enhanced learning: The role of theory. In H. Beetham \& R. Sharpe (Eds.), Rethinking pedagogy for a digital age: Designing for 21st century learning (2nd ed., pp. 20-29). New York, NY: Routledge.

Moskal, P., Dziuban, C., \& Hartman, J. (2013). Blended learning: A dangerous idea? https://doi.org/10.1016/j.iheduc.2012.12.001

Pihama, L. (2010). Kaupapa Māori theory: Transforming theory in Aotearoa. He Pukenga Korero: A Journal of Māori Studies, 9(2), 5-14.

Plomp, T. (2013). Educational design research: An introduction. In T. Plomp \& N. Nieveen (Eds.), Educational design research (pp. 10-51). Enschede, Netherlands: SLO Netherlands Institute of Curriculum Development.

Sciascia, A., \& Aguayo, C. (2016). He whare ako, he whare hangarau. A house of learning, a house of technologies. Report. http://mobilelearners.nz

Smith, L. T. (2012). Decolonizing methodologies: Research and indigenous peoples (2nd ed.). London, England: Zed Books.

Author (year). Navigating new terrain: Designing blended learning to develop digital literacies for students in a tertiary institution. Doctoral thesis, University of Auckland, New Zealand.

Schwenger, B. (2020). Should we care about what the students do? Challenging how we design for online learning. In S. Gregory, S. Warburton, \& M. Parkes (Eds.), ASCILITE's First Virtual Conference. Proceedings ASCILITE 2020 in Armidale (pp. 101-105). https://doi.org/10.14742/ascilite2020.0129

Note: All published papers are refereed, having undergone a double-blind peer-review process.

The author(s) assign a Creative Commons by attribution licence enabling others to distribute, remix, tweak, and build upon their work, even commercially, as long as credit is given to the author(s) for the original creation.

(C) Schwenger, B. 2020 